\title{
Fair trade information eliminates the positive brand effect: product choice behavior in Japan
}

\author{
Masaya Ota* (D), Yusuke Sakata and Takao lijima
}

\author{
*Correspondence: mota@fuk.kindai. \\ ac.jp \\ Department of Business and \\ Management, KINDAI University, \\ 820-8555 11-6, Kayanomori, \\ lizuka-city, Fukuoka, Japan
}

\begin{abstract}
We examine whether Fair Trade information affects the Japanese consumer's willingness to pay. We provide information on agroforestry and poverty resolution for chocolate products to test consumer behavior. We use an online survey and the Discrete Choice Experiment (DCE) method for hypothesis verification. The results show that brand has a positive effect on consumer willingness to pay, a negative effect in combination with agroforestry information, and no effect in combination with poverty resolution. In light of our results and discussions, to alleviate the above mentioned negative effect, we concluded that Japanese companies and universities should develop their corporate brand image along with their engagement in activities concerning Fair Trade and Japanese government should support to create their image to be engaged in activities concerning Fair Trade.
\end{abstract}

Keywords: Ethical marketing, Ethical consumers, Choice experiment, Brand trust, Causerelated marketing

\section{Introduction}

The 2030 Agenda for Sustainable Development of United Nations has 17 Sustainable Development Goals (SDGs). Goal 12 of SDGs focuses on sustainable consumption and production. This goal asks companies to reduce resource use, degradation, and pollution along the whole life cycle. Additionally, target 12.8 requires people to "have the relevant information and awareness for sustainable development and lifestyles in harmony with nature" by 2030 (United Nations 2015). Recently, a new type of consumer, the ethical consumer, has emerged, who considers the ethical attributes of a product at the manufacturing stage. Companies implement so-called ethical marketing strategies to appeal to this type of consumer. Ethical marketing is a type of cause-related marketing (Barone et al. 2000). The rise in this type of consumers and marketing would help achieve goal 12 of the SDGs.

Fair Trade products are a type of products preferred by ethical consumers. Fair Trade is a trade method that emphasizes on factors such as the well-being of the producer, or concern for the living things in an ecosystem within which the commodity is produced. Fair Trade was originally introduced as a critique of historically rooted international trade inequalities and had a small market in the 1960s and 1970s (Moore 2004; Raynolds 2009). As its market increased to 7.88 billion Euro (947 billion yen) in

(c) The Author(s). 2019 Open Access This article is distributed under the terms of the Creative Commons Attribution 4.0 International License (http://creativecommons.org/licenses/by/4.0/), which permits unrestricted use, distribution, and reproduction in any medium, provided you give appropriate credit to the original author(s) and the source, provide a link to the Creative Commons license, and indicate if changes were made. 
2016, Fair Trade came to be known as market-based initiatives (Fairtrade International 2017; Raynolds 2009).

In the 1980s, a Fair Trade label for coffee was introduced to reach the broader public (World Fair Trade Organization 2017). As pointed out by them, "Labeling has helped Fair Trade to go into mainstream business. Currently, over two-thirds of Fair Trade products are sold by mainstream catering and retailing."

Fair Trade includes many aspects, ranging from elimination of child poverty to environmentally friendly production methods. The World Fair Trade Organization (WFTO) prescribes ten principles that Fair Trade organizations must follow in their day-to-day work (World Fair Trade Organization 2017). The fifth principle prescribes elimination of child labor, which is caused by poverty (World Fair Trade Organization 2017; Harrison et al. 2005; Newholm and Shaw 2007). Principle 10 prescribes respect for the environment and requires agricultural commodity producers to "minimize their environmental impact by using organic or low pesticide production methods wherever possible" (World Fair Trade Organization 2017). This study focuses on these two principles in order to gage consumer response to Fair Trade products.

While Japan accounted for $6 \%$ of the world's GDP, its share in the world Fair Trade market was only $1.2 \%$ in $2016 .{ }^{1}$ On the other hand, $25.7 \%$ of Japanese consumers were aware of Fair Trade products in 2011, and this increased to 29.3\% in 2015 (Japan Fair Trade Forum 2015).

The small Fair Trade market and the rising awareness of the concept in Japan might suggest that Fair Trade awareness does not necessarily result in actual purchases.

In other words, while consumers understand the concept of Fair Trade, they do not necessarily choose a Fair Trade product while shopping. In this regard, Carrigan and Attalla (2001) and Tallontire et al. (2001) point out that, although consumers consider Fair Trade at the time of product selection, the weight of this criterion is not significant in their choice.

Recent literature has shown the effectiveness of Fair Trade information on the products' choice. For example, according to Lee et al. (2019), green certificates and awards have a positive impact on a company's brand image, and the brand image in turn increases its perceived value. De Pelsmacker, Driesen, \& Rayp (De Pelsmacker et al. 2005a, b) investigate the relative importance of different attributes on consumers' coffee-buying decision and confirm that brand attribute has the highest relative importance, followed by the Fair Trade label, which is the second highest by a small margin. De Pelsmacker et al. (2005a, b) also point to the effectiveness of combining a manufacturer brand with a Fair Trade label. Hustvedt and Bernard (2010) found that the stronger the Fair Trade interest is, the greater is the positive influence of social responsibility labeling on the willingness to pay for apparel. Additionally, the positive influence increases with the addition of brand names.

Although recent studies have shown that Fair Trade information has positive effects, none of them have tried to reveal the effectiveness of Fair Trade information on the products' choice in Japan. Therefore, this study tries to answer the following research questions.

${ }^{1}$ The estimated market size of international Fair Trade certified products is about 7.88 billion Euro, or about 947 billion yen according to the average exchange rate in 2016. Further, the market size in Japan increased by $13 \%$ to 11,360 million yen in 2016 compared to the previous year. (Fairtrade Label Japan 2016). 
a. Whether Fair Trade information (organic farming and poverty or child labor resolution) is effective on Japanese consumer's willingness to pay.

b. Whether Japanese consumers can process multiple Fair Trade information.

c. How do Japanese consumers perceive Japanese companies and universities that have the brand power to use Fair Trade information for their products.

The Japanese universities are included in the third research question because the Institute for International Trade and Investment (2017) has suggested the promotion of Fair Trade in Japan by local governments, citizens, companies, universities, and schools. The Japan Fair Trade Forum set the standards for Fair Trade universities in 2017. Fair Trade universities promote the concept of Fair Trade through various college-level classes, and their purpose is to enhance the understanding of Fair Trade in their respective regions by organizing awareness activities. Shizuoka University of Art and Culture was the first to be certificated in 2018 in Japan (Hamamatsu Keizai shinbun 2018), and some other universities are also aiming for the Fair Trade certification. Shizuoka University of Art and Culture develops their original Fair Trade products (Hamamatsu Keizai shinbun 2018), and thus, there is a possibility that other Fair Trade universities will also develop such products from now on. Therefore, we included Japanese universities in the abovementioned third research question. In addition, no study has tried to investigate the relationship between university brand, Fair Trade information, and willingness to pay. Understanding this relationship can contribute to the Fair Trade universities, along with universities around the world considering the Fair Trade certification.

The structure of this article as follows. In Section 2, we formulate hypotheses about the effect of Fair Trade information (organic farming and poverty or child labor resolution) and brand on consumer willingness to pay. Section 3 explains our research methods to verify the hypotheses defined earlier, and Section 4 presents the results and discussions. Section 5 provides the conclusion of the study and outlines options for future research.

\section{The effect of fair trade information and brand on willingness to pay Organic farming}

Agroforestry $^{2}$ provides appropriate levels of income to producers and maintains forest ecosystems and can be considered a type of organic farming. This type of farming has been widely used for cacao and coffee cultivation in recent years. Cacao cultivation by agroforestry improves farm ecosystems and productivity. For instance, Van Bael et al. (2007) point out that, with agroforestry, the ecosystems of cacao farms greatly improved, and more birds inhabit the forests. Further, Tscharntke et al. (2011) showed that agroforestry, in addition to improving biodiversity, mitigates various climate change effects by producing carbon sinks, while Armengot et al. (2016) reveal that agroforestry doubles productivity compared with traditional farming.

The important factors of organic farming that consumers are mostly concerned about are their health and the preservation of the ecosystem (Ghvanidze et al. 2017). Many

${ }^{2}$ Agroforestry is a type of managing trees by an environmentally friendly method to protect natural ecosystems. Forests managed under agroforestry systems resembles natural forest. People can harvest multiple crops, such as coffee, timber woods, fruits and vegetables. (Van Bael et al. 2007; Pardon et al. 2018) 
studies reveal that organic farming improves the ecosystem of the farmland. For instance, the heavy use of pesticides in large-scale plantations such as those for cacao in developing countries negatively affects the area's ecosystems (Sigel et al. 2006). On the other hand, it is generally difficult to establish whether organic products are healthier for consumers than ordinary products.

Rousseau and Vranken (2011) reveal that organic labels increase consumer WTP, even without considering any possible health effects. Our research follows previous work which evaluates consumer WTP for organic products in regard to ecosystem improvement, as in Rousseau and Vranken (2011).

Thus, we may make the assumption that agroforestry attracts ethical consumers, especially those interested in environmental issues. We formulate hypothesis 1 as follows:

H1: Information about agroforestry on product packaging raises consumer WTP.

\section{Poverty and child labor}

Some forms of ethical consumption benefit poverty or child labor resolution while others benefit natural environment (De Pelsmacker et al. 2005a, b). When ethical consumers buy chocolate bars, they likely also care about poor children in the world because raw materials for chocolate are produced in some of the impoverished areas on the globe (Schrage and Ewing 2005; Baradaran and Barclay 2011).

Cote d'Ivoire and Ghana accounted for $42 \%$ and $17 \%$ of the world's cocoa production in 2014 and 2015 respectively (International Cocoa Organization 2017). However, in 2013, Sub-Saharan nations accounted for $50.7 \%$ of the poor who live below the international poverty line, which is 1.90 US dollars per day (World Bank 2016). In that same year, $41 \%$ of the region's population was impoverished (World Bank 2016), with poverty directly affecting $22.4 \%$ of the region's children aged 5 to 17 , thus leading to increased rates of child labor. Moreover, the agricultural sector accounts for $85.1 \%$ of child labor in Africa (International Labour Office 2017).

De Pelsmacker et al. (2005a, b) found that the average price premium that the consumers were willing to pay for a Fair Trade label was $10 \%$ in the Belgian coffee market. Chocolate is the second largest product after coffee in the Fair Trade market in Japan (Fairtrade Label Japan 2016, 2017). Thus, ethical consumption is also likely to be observed in the Japanese chocolate market, and this is likely to increase purchasing probability when a chocolate product package includes information on poverty and/or child labor reduction.

Therefore, we formulate hypothesis 2 as follows:

$\mathrm{H} 2$ : Information on poverty and/or child labor reduction on product packaging increases consumer WTP.

Producers, manufactures, and retailers often use certification marks for Fair Trade and ethical marketing. Such certification marks embody Fair Trade values, which include several concepts such as an organic farming and poverty elimination. However, when consumers recognize the value of both organic farming and poverty elimination simultaneously, their WTP from the simultaneous recognition of both values might be lower than the sum of the WTP upon recognition of each value, owing to their budget constraints. 
In other words, consumers have limited ability to pay for the product's combined economic and ethical values. While they are willing to pay a certain amount for each value (i.e., either organic farming or poverty elimination), they are less willing to pay for both ethical values when they are simultaneously presented.

Regarding this point, Didier and Lucie (2008) verify the hypothesis that the joint application of organic and Fair Trade labels on a product induces sub-additively to the WTP compared with the case when the two labels are applied separately. In their study, WTP increased to 1.25 Euro with the organic label, 1.31 Euro with the Fair Trade label but remained at 1.61 Euro with the joint label. On the contrary, Poelman et al. (2008) resulted that the consumer's attitudes toward attributes of organic and Fair Trade for pineapples were uncorrelated. Then, we evaluated the correlations and the additivity of ethical values by formulating hypothesis 3 as follows:

H3: When a product's packaging is labeled with multiple ethical values, consumer WTP is the sum of the WTP from each value or less.

\section{Brand}

Keller (1993) defines brand as that a brand "the differential effect of brand knowledge on consumer response to the marketing mix of the brand" (Keller 1993, p.8). In addition, a brand has positive (negative) customer-based brand equity, "when the consumer is familiar with the brand and holds some favorable, strong, and unique brand associations in memory" (Keller 1993, p.2). Most brand-related studies conclude that positive brand equity increases the willingness to pay a price premium for the brand (Dwivedi et al. 2018; Netemeyer et al. 2018; Jina et al. 2011; Kalra and Goodstein 1998; Aaker 1996; Park and Srinivasan 1994; Keller 1993). Park and Srinivasan (1994) reveal that major brands in the toothpaste market, which accounts for $80 \%$ of the share in the United States, are able to charge above the price of an identical product with a store brand. Kalra and Goodstein (1998) also verify the effect of brand equity on the willingness to pay for photographic cameras. As a result, consumers were more willing to pay for the premium brand (Nikon) relative to the minor brand (Sigma), despite using the same advertising contents. Further, Jina et al. (2011) show similar results to Park and Srinivasan (1994) and Kalra and Goodstein (1998) for various other product categories (electronics, clothing, processed food, and fresh produce). Thus, we formulate hypothesis 4 as follows to ensure our survey follows the previous studies;

H4: When a product brand is familiar to a consumer, consumer WTP increases.

Fatma and Rahman (2017) point out that brands that consumers perceive as engaging in ethical behavior significantly influence consumer behavior. For instance, Singh et al. (2012) confirm that the stronger the consumer ethical recognition of a brand (the extent to which they think a brand to be ethical), the greater the positive influence of brand trust on brand loyalty will be, expressed in terms of brand repurchase intention. Hustvedt and Bernard (2010) verify that the combined effect of brand and social responsibility labelling (labor-related labels like "sweatshop free") have a positive effect on WTP for apparel, and this positive effect is enhanced when brand attributes are added. Therefore, the effect of brand familiarity on consumer product choice may be enhanced by a brand's ethical behavior (e.g., as indicated by information provided on agroforestry or poverty). Thus, we formulate hypothesis 5 as follows: 
H5: The effect of brand familiarity on consumer WTP increases when combined with information about the brand's ethical values.

\section{Research design}

Research methodology: discrete choice experiment and decision of attributes and levels In order to test above hypotheses, we need to know consumer's preference and WTP for each attribute about Fair Trade information (organic farming, and poverty and child labor) and brand. So, we used Discrete Choice Experiment (DCE) method which involves asking individuals to state their preference over hypothetical alternative scenarios, goods or services (Mangham et al. 2009). DCE is a type of conjoint analysis which was originally developed for marketing research (Louviere and Woodworth 1983; Louviere et al. 2010). DCE is the preferred method for evaluating added-value products with multiple attributes simultaneously, such as the ones we consider in this study (Aizaki et al. 2015).

In the DCE analysis, respondents choose one of several products presented, each of which has a number of attributes. We assume that the chosen alternative maximizes buyer utility. This process is similar to actual buying behavior. Thus, DCE is considered to produce results that are the closest to actual consumption behavior.

DCE also enables the estimation of consumer WTP. The method is consistent with economic theory, and random utility theory reveals the marginal utility of each attribute. (Lancaster 1966; McFadden 1974; Louviere 1988; Green and Srinivasan 1990; Hensher 1994).

Based on our hypotheses, the following attributes were evaluated in the DCE, such as agroforestry practice (hereafter "Organic"), producer standard of living (hereafter "Poverty"), manufacturer brand (hereafter "Brand"), and university brand (hereafter "University").

The levels for each attribute are set as follows. Organic was set to two levels, namely, "implementation of forest farming method considering ecological protection" ("Ecological protection" in Table 1) and "conventional agriculture method not particularly concerned with ecological protection" ("Conventional" in Table 1). Poverty was set to two levels indicating "adequate standard of living" and "child labor owing to poverty." Brand was set to two levels indicating "major confectionery manufacturers" ("Major" in Table 1) and "unknown manufacturers" ("Unknown" in Table 1). Finally, University was also set to two levels according to the "existence of collaboration with familiar universities" ("With collaboration" and "No collaboration" in Table 1). The product package did not feature labels for "Conventional," "Adequate standard of living," or "No collaboration," but featured a label for "Unknown."

\section{Profile design}

We constructed profiles for our DCE based on five attributes (four attributes and price [hereafter "Price"]). We set Price to three levels (i.e., 125-yen, 150-yen, and 100-yen,

Table 1 Profile Design for the experiments

\begin{tabular}{lllll}
\hline Price & Organic & Poverty & Brand & University \\
\hline 100 yen & Conventional & Adequate standard of living & Unknown & No collaboration \\
125 yen & Ecological protection & Poverty and child labor & Major (e.g., Morinaga) & With collaboration \\
150 yen & - & - & - & - \\
\hline
\end{tabular}


which is assumed as the price of a standard chocolate bar). The level of each attribute is shown in Table 1.

From the total of 48 combinations of the above attribute levels, 16 profiles were extracted by orthogonal planning using the AlgDesign package for the R Statistical Software implementation ( $\mathrm{R}$ Core Team 2018; Wheeler 2006). We randomly extracted two of these profiles and set 16 questions for three choice formulas, which include "Neither."

\section{Survey}

Our research was conducted through an online survey entitled "A Survey on Chocolates" on December 11, 2017. Questant, a service of Macromill, Inc., implemented our online survey with their monitors.

We implemented a pilot test from 15 to 17 September. Thirty four university students cooperated to the test. We improved images of Chocolate products because some respondents claimed that the explanation was difficult to understand.

We split the respondents into Groups A and B. As Table 2 shows, the demographic attributes of both groups were very similar.

Our survey sheet has four parts. The first part introduced agroforestry and child labor. The second part collected attitudes toward environmental problems. The third part contained choice experiments, for which we provided different choice sets with eight choices for Groups A and B. The last part collected demographic features. The results show that male respondents accounted for over $50 \%$ of the total. The descriptive statistics show that we had a rather flat distribution for age groups, except for the group under 19 years of age, and almost $50 \%$ of the respondents had at least a bachelor's degree.

\section{Correspondence between analysis model and hypotheses}

We analyze the data using a conditional logit model, which is the most widely used basic model in DCE analysis. In DCE analysis, the utility of an option may be confirmed according to the sign and magnitude of the coefficient estimate of the variable. A positive sign of a coefficient estimate indicates a positive value and consequently, a positive utility of the option. Conversely, when the sign of each coefficient estimate value is negative, it indicates that the smaller its value, the smaller the utility of that option (Aizaki and Nishimura 2007).

We set a base model (Model 1), which includes five attributes: Price, Organic, Poverty, Brand, and University. $V$ in the model indicates measurable utility:

(Model 1) $V_{1}=\beta_{\text {pri }} \cdot$ PRICE $+\beta_{\text {org }} \cdot$ ORGANIC $+\beta_{\text {pov }} \cdot$ POVERTY

$$
+\beta_{\text {bra }} \cdot \text { BRAND }+\beta_{\text {uni }} \cdot \text { UNIVERSITY }
$$

With Model 1, hypothesis 1 is supported if the coefficient estimate of Organic is significantly positive, hypothesis 2 is supported if the coefficient estimate of Poverty

\footnotetext{
${ }^{3}$ The option to respond "Neither" was provided in questions that involve the purchase of a 100-yen chocolate bar that is produced by an unknown manufacturer and that does not provide information on farming method, producer standard of living, or university collaboration.
} 
Table 2 Demographic attributes of Groups A and B

\begin{tabular}{|c|c|c|c|c|}
\hline \multirow{2}{*}{$\overline{\text { Sex }}$} & \multicolumn{2}{|c|}{ Group A } & \multicolumn{2}{|c|}{ Group B } \\
\hline & & & & \\
\hline Male & 315 & $57.0 \%$ & 311 & $55.8 \%$ \\
\hline Female & 238 & $43.0 \%$ & 246 & $44.2 \%$ \\
\hline Total & 553 & $100 \%$ & 557 & $100 \%$ \\
\hline \multicolumn{5}{|l|}{ Age } \\
\hline Under 19 & 6 & $1.1 \%$ & 4 & $0.7 \%$ \\
\hline 20-39 & 40 & $7.2 \%$ & 40 & $7.1 \%$ \\
\hline $30-39$ & 97 & $17.5 \%$ & 82 & $14.8 \%$ \\
\hline $40-49$ & 142 & $25.6 \%$ & 163 & $29.2 \%$ \\
\hline $50-59$ & 130 & $23.5 \%$ & 138 & $24.8 \%$ \\
\hline $60-69$ & 99 & $17.9 \%$ & 98 & $17.6 \%$ \\
\hline $70-$ & 39 & $7.1 \%$ & 32 & $5.7 \%$ \\
\hline Total & 553 & $100 \%$ & 557 & $100 \%$ \\
\hline \multicolumn{5}{|l|}{ Education } \\
\hline Master's or doctoral degree & 26 & $4.7 \%$ & 21 & $3.8 \%$ \\
\hline Bachelor's degree & 252 & $45.6 \%$ & 239 & $42.9 \%$ \\
\hline Junior college & 51 & $9.2 \%$ & 58 & $10.4 \%$ \\
\hline Vocational school & 52 & $9.4 \%$ & 60 & $10.8 \%$ \\
\hline High school & 156 & $28.2 \%$ & 157 & $28.2 \%$ \\
\hline Others & 16 & $2.9 \%$ & 22 & $3.9 \%$ \\
\hline Total & 553 & $100 \%$ & 557 & $100 \%$ \\
\hline
\end{tabular}

is significantly positive, and hypothesis 4 is supported if the coefficient estimate of Brand and/or University is significantly positive. By using a cross-term, it is possible to check how variable $A$ is influenced by variable $B$ in terms of the option utility (Aizaki and Nishimura 2007). For example, a positive coefficient estimate of the cross-term of Poverty and Brand (PovBra) means that people who are concerned about the issue of poverty have a good impression of the brand and have a strong tendency to select the brand's products.

We set Model 2 by adding the cross-term of Organic and Poverty (OrgPov) to Model 1 to analyze consumer understanding and attitudes toward the concept of ethics (i.e., being ethical):

(Model 2) $V_{2}=\beta_{p r i} \cdot$ PRICE $+\beta_{\text {org }} \cdot$ ORGANIC $+\beta_{\text {pov }} \cdot$ POVERTY

$$
+\beta_{b r a} \cdot B R A N D+\beta_{\text {uni }} \cdot \text { UNIVERSITY }+\beta_{\text {orgpov }} \cdot \text { ORGANIC.POVERTY }
$$

In Model 2, we verify that hypothesis 3 is supported if the coefficient estimate of the cross-term is significantly positive. Analogously, to analyze the relationship between brands and ethical advertisements, we set Model 3 by adding the cross-term of Organic and Brand (OrgBra) to Model 1, Model 4 is obtained by adding the cross-term PovBra to Model 1, Model 5 is obtained by adding the cross-term of Organic and University (OrgUni) to Model 1, and Model 6 is obtained by adding the cross-term of Poverty and University (PovUni) to Model 1: 
(Model 3) $V_{3}=\beta_{\text {pri }} \cdot$ PRICE $+\beta_{\text {org }} \cdot$ ORGANIC $+\beta_{\text {pov }} \cdot$ POVERTY

$$
\begin{aligned}
& +\beta_{\text {bra }} \cdot \text { BRAND }+\beta_{\text {uni }} \cdot \text { UNIVERSITY }+\beta_{\text {orgbra }} \cdot \text { ORGANIC } \cdot \text { BRAND } \\
& \left(\text { Model 4) } V_{4}=\beta_{\text {pri }} \cdot \text { PRICE }+\beta_{\text {org }} \cdot \text { ORGANIC }+\beta_{\text {pov }} \cdot\right. \text { POVERTY } \\
& +\beta_{\text {bra }} \cdot \text { BRAND }+\beta_{\text {uni }} \cdot \text { UNIVERSITY }+\beta_{\text {povbra }} \cdot \text { POVERTY BRAND }
\end{aligned}
$$

$\left(\right.$ Model 5) $V_{5}=\beta_{p r i} \cdot$ PRICE $+\beta_{\text {org }} \cdot$ ORGANIC $+\beta_{\text {pov }} \cdot$ POVERTY

$$
+\beta_{\text {bra }} \cdot \text { BRAND }+\beta_{\text {uni }} \cdot \text { UNIVERSITY }+\beta_{\text {orguni }} \cdot \text { ORGANIC } \cdot \text { UNIVERSITY }
$$

(Model 6) $V_{6}=\beta_{p r i} \cdot$ PRICE $+\beta_{\text {org }} \cdot$ ORGANIC $+\beta_{p o v} \cdot$ POVERTY

$$
+\beta_{b r a} \cdot \text { BRAND }+\beta_{\text {uni }} \cdot \text { UNIVERSITY }+\beta_{\text {povuni }} \cdot \text { POVERTY UNIVERSITY }
$$

In Models 3, 4, 5, and 6, we verify that hypothesis 5 is supported if the coefficient estimate of each cross-term is significantly positive.

To estimate Models 1-6, we added error terms $\varepsilon_{i}$, $i$ represented model number, and got the following observable utility, $U_{i}$.

$$
U_{i}=V_{i}+\varepsilon_{i}
$$

We estimated Models 1-6 using the conditional logit model with the $\mathrm{R}$ Statistical Software ( $\mathrm{R}$ Core Team 2018). We can use the conditional logit model to estimate the probability when the random terms have an identified independent distribution. (McFadden 1974).

In the DCE, WTP can be obtained by dividing the coefficient estimate of the nonprice attribute variable (Organic, Poverty, Brand, and University) by the coefficient estimate of the price attribute variable (Price) and then multiplying the result by -1 . This WTP represents the utility of non-price attribute variable options in monetary terms (Aizaki and Nishimura 2007). Therefore, regarding Model 1, in addition to the above items, WTP was also calculated and the validity of each hypothesis was tested.

\section{Results and discussion}

\section{Results}

We aggregated the survey responses and estimated the parameters of each model (Table 3 and Table 4). We calculated the WTP for each attribute in Model 1, and the individual WTPs are: 19.8 yen (Organic), 22.5 yen (Poverty), 27.3 yen (Brand), and - 2.5 yen (University) (Table 3).

Using Models 1 and 2, we examine the relationship between Organic and Poverty. The estimation results in Model 1 show that the coefficients of Organic and Poverty were both significant and positive, thus supporting hypotheses 1 and 2 .

Next, we examine the cross effects of Organic and Poverty to test hypothesis 3. The cross-term was assumed to represent Fair Trade. The results show that the cross-term was significantly positive as the coefficients of Organic and Poverty.

The estimation results from Model 2 show that the sum of the coefficients of Organic, Poverty, and OrgPov was 0.90, which is smaller than the sum of the coefficients of Organic and Poverty (0.93) from Model 1. This result supports hypothesis 3.

Next, we discuss the relationships between Brand, Organic, and Poverty. The results from Model 1 show a significant positive influence of Brand on consumer purchase intention, 
Table 3 Parameter estimation results (Models 1 and 2)

\begin{tabular}{|c|c|c|c|c|c|}
\hline & \multicolumn{3}{|l|}{ Model 1} & \multicolumn{2}{|l|}{ Model 2} \\
\hline & Coef. & $p$ & WTP & Coef. & $p$ \\
\hline Price & -0.021865 & $0.000^{* * *}$ & & -0.020054 & $0.000^{* * *}$ \\
\hline Organic & 0.433919 & $0.000^{* * *}$ & 19.8 & 0.272668 & $0.000^{* * *}$ \\
\hline Poverty & 0.492928 & $0.000^{* * *}$ & 22.5 & 0.314347 & $0.000^{* * *}$ \\
\hline Brand & 0.599516 & $0.000^{* * *}$ & 27.4 & 0.637816 & $0.000^{* * *}$ \\
\hline University & -0.055038 & $0.041^{* *}$ & -2.5 & -0.028807 & 0.3 \\
\hline OrgPov & & & & 0.315809 & $0.000^{* * *}$ \\
\hline
\end{tabular}

Notes ${ }^{* *} p<.01,{ }^{* *} p<.05$, and ${ }^{*} p<.10$

Coef. Coefficient

OrgPov Cross-term of Organic and Poverty

WTP Willingness to pay

indicating that hypothesis 4 is supported. However, Model 3, which includes the interaction term of Brand and Organic (OrgBra), and Model 4, which includes the interaction term of Brand and Poverty (PovBra), indicate the use of certification marks by a major confectionery manufacturer and produced different results regarding hypotheses 5 .

The results for University were the same as those for Brand. Significant negative effects were observed from both Model 5, which includes the interaction term of University and Organic (OrgUni), and Model 6, which includes the interaction term of University and Poverty (PovUni), thus indicating the use of certification marks by universities. The coefficient of OrgUni in Model 5 (-0.301346) is larger than that of OrgBra in Model $3(-0.239969)$. In other words, University's reliability is significantly impaired when the variable is combined with Organic, just as the case when Brand is combined with Organic. PovUni in Model 6 has a significant negative influence at the $10 \%$ level but a small coefficient $(-0.11707)$.

\section{Discussion}

The variables Organic and Poverty have a significant positive effect on consumer purchase intention, and the WTPs for both attributes are 19.5 yen in Organic and 22.5 yen in

Table 4 Parameter estimation results (Models 3-6)

\begin{tabular}{|c|c|c|c|c|c|c|c|c|}
\hline & \multicolumn{2}{|l|}{ Model 3} & \multicolumn{2}{|l|}{ Model 4} & \multicolumn{2}{|l|}{ Model 5} & \multicolumn{2}{|l|}{ Model 6} \\
\hline & Coef. & $p$ & Coef. & $p$ & Coef. & $p$ & Coef. & $p$ \\
\hline Price & -0.021111 & $0.000^{* * *}$ & -0.021833 & $0.000^{* * *}$ & -0.023641 & $0.000^{* * *}$ & -0.02189 & $0.000^{* * *}$ \\
\hline Organic & 0.508233 & $0.000^{* * *}$ & 0.435342 & $0.000^{* * *}$ & 0.551634 & $0.000^{* * *}$ & 0.41788 & $0.000^{* * *}$ \\
\hline Poverty & 0.468075 & $0.000^{* * *}$ & 0.482128 & $0.000^{* * *}$ & 0.488216 & $0.000^{* * *}$ & 0.54266 & $0.000^{* * *}$ \\
\hline Brand & 0.694876 & $0.000^{* * *}$ & 0.587296 & $0.000^{* * *}$ & 0.586736 & $0.000^{* * *}$ & 0.5898 & $0.000^{* * *}$ \\
\hline University & -0.086798 & $0.002^{* * *}$ & -0.0528 & $0.055^{*}$ & 0.077635 & $0.07762^{*}$ & -0.00599 & 0.877 \\
\hline OrgBra & -0.239969 & $0.000^{* * *}$ & & & & & & \\
\hline PovBra & & & 0.025004 & 0.674 & & & & \\
\hline OrgUni & & & & & -0.301346 & $0.000^{* * *}$ & & \\
\hline PovUni & & & & & & & -0.11707 & $0.079^{*}$ \\
\hline
\end{tabular}

Notes $^{* * *} p<.01,{ }^{* *} p<.05$, and ${ }^{*} p<.10$

Coef. Coefficient

OrgBra The cross term of Organic and Brand

PovBra The cross term of Poverty and Brand

OrgUni The cross term of Organic and University

PovUni The cross term of Poverty and University 
Poverty. Tully and Winer (2014) verified whether the beneficiary of the social responsibility program (humans, animals, or the environment) affects WTP using a meta-analysis. As a result, WTP is greater for products where the social responsibility benefits humans and animals compared to products that benefit the environment. Our result is consistent with the results from Tully and Winer (2014). Japanese consumers place more value on package information about eliminating poverty than about maintaining ecosystems. However, the combined effect of Organic and Poverty is negative on consumer purchase intention. This result is consistent with Didier and Lucie (2008), who confirm that some French consumers prefer an organic product to an organic and Fair Trade product, and the results from Poelman et al. (2008), who confirm that a single message about organic production or about Fair Trade production is preferable to multiple messages for British and Dutch consumers. Japanese consumers also prefer a single message about maintaining forest ecosystems, or about eliminating poverty, as opposes to a combined message.

The results from Model 3 show a significantly negative effect of OrgBra, while those from Model 4 do not show a significant influence of PovBra. These results show that Brand has a positive effect on general merchandise sales on its own, but a negative effect in combination with Organic, and no effect whatsoever in combination with Poverty. In recent years, many companies have stated their contributions to improving society and the environment. However, they have not disclosed the outcomes of their contributions, and thus Japanese consumers still appear to be skeptical of such companies (Nyilasy et al. 2014; Poelman et al. 2008).

OrgBra's significant negative impact is probably due to the great skepticism on the part of Japanese consumers about the claim that major confectionery manufacturers use agroforestry. In a survey of 1000 consumers, The Soil Association (2017) found that $72 \%$ of respondents believed beauty brands labeled "organic" were "not reliable," and it pointed out that the cause of this skepticism was made by major beauty brands such as intentionally misleading or deceiving consumers with false claims about maintaining forest ecosystems. Meanwhile, PovBra's insignificant influence is also due to the same type of skepticism. Fatma and Rahman (2017) show that brands recognized as having ethical behavior positively influence consumer behavior. Lee et al. (2019) also show that brand image recognized as practicing green management has positive impact on brand perceived value, and then which value leads to positive behavioral intentions. Therefore, we consider that Japanese consumers may judge whether the companies using Fair Trade information on their product labels are actively engaged in maintaining forest ecosystems and/or eliminating poverty as a whole or not. If Japanese consumers recognize a company as actively being engaged in activities concerning Fair Trade, they may not doubt their claims about their use of agroforestry or their contribution to poverty elimination, thus increasing their purchasing intention. If they are not recognized in this manner, Japanese consumers may be skeptical of their claims and therefore their purchase intention may decline. This effect is especially apparent when a company introduces its agroforestry initiatives. De Pelsmacker et al. (2005a, b) point out the importance to include extra information about Fair Trade label on the back of package. In Japan, companies should need to provide not only Fair Trade label but also information of their efforts on Fair Trade. The same line of thought applies to university brand. For universities, developing products in collaboration with the industrial sector that use agroforestry and that help eliminate poverty is not a very effective way to improve 
purchase intentions. Instead, becoming a certified Fair Trade University may be a more effective way to improve purchase intentions, as the certification of Fair Trade University proves that the specific school is actively engaged in activities concerning Fair Trade.

\section{Conclusions and future research}

This study revealed the following:

a) Fair Trade information (organic farming and poverty or child labor resolution) is effective on Japanese WTP.

b) Japanese consumers cannot process multiple Fair Trade information. They prefer a single message about maintaining forest ecosystems or eliminating poverty, as opposed to a combined message.

c) Japanese consumers are skeptical toward Fair Trade information promoted by companies and universities that have brand power.

Fair Trade information such as maintaining forest ecosystems and eliminating poverty are effective tools in ethical marketing for Japanese consumers, but ethical marketing and brand image had a small synergistic effect on WTP. This latter finding is in consistent with previous studies (Fatma and Rahman 2017; Hustvedt and Bernard 2010; Singh et al. 2012; De Pelsmacker et al. 2005a, b).

As mentioned above, Japan's share in the world Fair Trade market is small in spite of a high GDP. Japanese companies have introduced Fair Trade information such as maintaining forest ecosystems and eliminating poverty to marketing activities for their products in recent years. However, in light of our results, they should simultaneously develop their corporate brand images to engage in activities concerning Fair Trade. In addition, Japanese universities should develop their images to engage in activities concerning Fair Trade. Fair Trade University policy appears to be helpful in developing such images.

Japanese government has actively pursed SDGs since the launch of SDGs Promotion Headquarters on May 20, 2016 (Ministry of Foreign Affairs of Japan 2017), but their activities are not recognized by Japanese consumers. According to the survey by DENTSU MACROMILL INSIGHT, INC. (2019), 16\% of Japanese consumers were aware of SDGs and only $4.2 \%$ recognized and understood SDGs. ${ }^{4}$ To resolve this problem, Japanese government should support the development of company and university image for engaging in activities concerning Fair Trade, such as providing a subvention for those who want to promote their activities concerning Fair Trade.

Our research findings may not be generalizable, as it involved only one product type (chocolate). Therefore, it is necessary to conduct similar research on other product types or categories. Additionally, consumer characteristics should be considered. Confirming the generalizability of our findings is important to help policy makers, business sectors, and educators-in the same situation as Japan-improve the effectiveness of their Fair Trade efforts in changing consumer buying behavior.

${ }^{4}$ This survey was conducted to 6576 Japanese people from teenage to seventies (Hayashi 2019). 


\section{Abbreviations}

Brand: Manufacturer brand; Conventional: Conventional agriculture method not particularly concerned with ecological protection; DCE: Discrete Choice Experiment; Ecological: Implementation of forest farming method considering ecological protection; GDP: Gross Domestic Product; Major: Major confectionery manufacturers; Organic: Forest farming practice implementation; OrgBra: The cross-term of Organic and Brand; OrgPov: The cross-term of Organic and Poverty; OrgUni: The cross-term of Organic and University; PovBra: The cross-term of Poverty and Brand; Poverty: Producer standard of living; PovUni: The cross-term of Poverty and University; U: Observable utility; University: University brand; Unknown: Unknown manufacturers; V: Measurable utility; WFTO: The World Fair Trade Organization; With (No) collaboration: The existence of collaboration with familiar universities; WTP: Willingness to Pay

\section{Acknowledgements}

Not applicable.

\section{Authors' contributions}

First author conducted the brand related literature review, data collection and the statistical analysis. Second author conducted the organic related review, data collection and the statistical analysis. Third author conducted the poverty and child labor related literature review, data collection and the statistical analysis. All the authors read and approved the final manuscript.

\section{Funding}

The authors disclosed receipt of the following financial support for the research. This research was supported by Sumitomo Foundation (grant number 163301). This research was supported by JSPS KAKENHI (grant number 18 K12869).

\section{Availability of data and materials}

Please contact author for data requests.

\section{Competing interests}

The authors declare that they have no competing interests.

Received: 12 April 2019 Accepted: 27 June 2019

Published online: 22 July 2019

\section{References}

Aaker DA (1996) Measuring brand equity across products and markets. Calif Manag Rev 38(3):102-120

Aizaki H, Nakatani T, Sato K (2015) Stated preference methods using R. Chapman and Hall/CRC, New York

Aizaki H, Nishimura K (2007) Introduction to choice experiments using R. technical report of the National Institute for rural engineering, vol 206, pp 151-173 (in Japanese)

Armengot L, Barbieri P, Andres C, Milz J, Schneider M (2016) Cacao agroforestry systems have higher return on labor compared to full-sun monocultures. Agron Sustain Dev. https://doi.org/10.1007/s13593-016-0406-6

Baradaran S, Barclay S (2011) Fair trade and child labor. Columbia Human Rights Law Rev 43(1):1-63

Barone MJ, Miyazaki AD, Taylor KA (2000) The influence of cause-related marketing on consumer choice: does one good turn deserve another? J Acad Mark Sci 28(2):248-262

Carrigan M, Attalla A (2001) The myth of the ethical consumer - do ethics matter in purchase behaviour? J Consum Mark 18:550-578

De Pelsmacker P, Driesen L, Rayp G (2005a) Do consumers care about ethics? Willingness to pay for fair-trade coffee. J Consum Aff 39(2):363-385

De Pelsmacker P, Janssens W, Sterckx E, Mielants C (2005b) Consumer preferences for the marketing of ethically labelled coffee. Int Mark Rev 22(5):512-530

Didier T, Lucie S (2008) Measuring consumer's willingness to pay for organic and fair trade products. Int J Consum Stud 32(5):479-490

Dwivedi A, Nayeem T, Murshed F (2018) Brand experience and consumers' willingness-to-pay (WTP) a price premium: mediating role of brand credibility and perceived uniqueness. J Retail Consum Serv 44:100-107

Fairtrade International (2017) Creating Innovations, Scaling Up Impact [Annual Report 2016]. https://annualreport16-17. fairtrade.net/en/. Accessed 12 Jan 2019

Fairtrade Label Japan (2016) 2015 Nendo Jigyo Hokokusho [annual report 2015] https://www.fairtrade-jp.org/about_us/file/2 015_katsudo.pdf. Accessed 12 Jan 2019 (in Japanese)

Fairtrade Label Japan (2017) 2016 Nendo Jigyo Hokokusho [Annual Report 2016]. https://www.fairtrade-jp.org/about_us/file/2 016_katsudo.pdf. Accessed 12 Jan 2019 (in Japanese)

Fatma M, Rahman Z (2017) An integrated framework to understand how consumer-perceived ethicality influences consumer hotel brand loyalty. Serv Sci 9(2):136-146

Ghvanidze S, Velikova N, Dodd T, Oldewage-Theron W (2017) A discrete choice experiment of the impact of consumers' environmental values, ethical concerns, and health consciousness on food choices. Br Food J 119(4):863-881

Green E, Srinivasan V (1990) Conjoint analysis in marketing: new developments with implications for research and practice. J Mark Res 54:3-19

Hamamatsu Keizai shinbun (2018) Shizuoka Bunka Geijyutudaigaku ga Fair trade Daigaku Nintei. https://hamamatsu.keizai.biz/ headline/1972/. Accessed 2 June 2019 (in Japanese)

Harrison R, Newholm T, Shaw D (2005) The ethical consumer. Sage, Thousand Oaks

Hayashi Y (2019) Nihonni SDGs ha nezukuka?: Dai ni kai Dentsu SDGs seikatsusya tyousa karano kousatsu. https://dentsu-ho. com/articles/6615 Accessed 6 June 2019 (in Japanese)

Hensher DA (1994) Stated preference analysis of travel choices: the state of practice. Transportation 21:107-133

Hustvedt G, Bernard JC (2010) Effects of social responsibility labelling and brand on willingness to pay for apparel. Int J Consum Stud 34:619-626

Institute for International Trade and Investment (2017) New development of fair trade business model, FY2016 http://www. iti.or.jp/report_45.pdf. Accessed 21 Feb 2018 (In Japanese) 
International Cocoa Organization (2017) ICCO quarterly bulletin of cocoa statistics Vol. XLIII, no. 3, Cocoa year 2016/17 International Labour Office (2017) Global estimates of child labour: results and trends, 2012-2016 http://www.lo.org/ wcmsp5/groups/public/---dgreports/---dcomm/documents/publication/wcms_575499.pdf. Accessed 25 Feb 2019

Japan Fair Trade Forum (2015) The survey of fair-trade and ethical consumers in Japan, 2015 http://fairtrade-forum-japan.org/wpcontent/uploads/2018/05/cf020e27c8d1b54e75e1 1a073504a919.pdf. Accessed 25 Feb 2019 (in Japanese)

Jina YH, Zilberman D, Heimanc A, Lid Y (2011) Willingness to pay for brands: a cross-region, cross-category analysis. Agric Econ 42:141-152 Kalra A, Goodstein RC (1998) The impact of advertising positioning strategies on consumer price sensitivity. J Mark Res 35(2):210-224 Keller KL (1993) Conceptualizing, measuring, and managing customer-based brand equity. J Mark 57(1):1-22

Lancaster K (1966) A new approach to consumer theory. J Polit Econ 74:132-157

Lee K, Lee M, Gunarathne N (2019) Do green awards and certifications matter? Consumers' perceptions, green behavioral intentions, and economic implications for the hotel industry: a Sri Lankan perspective. Tourism Econ 25(4):593-612

Louviere JJ (1988) Conjoint analysis modeling of stated preferences: a review of theory, methods, recent developments, and external validity. J Transp Econ Policy 20:93-119

Louviere JJ, Flynn TN, Carson RT (2010) Discrete choice experiments are not conjoint analysis. J Choice Model 3(3):57-72

Louviere JJ, Woodworth G (1983) Design and analysis of simulated consumer choice or allocation experiments: an approach based on aggregate data. J Mark Res 20(4):350-367

Mangham LJ, Hanson K, McPake B (2009) How to do (or not to do) ... designing a discrete choice experiment for application in a low-income country. Health Policy Plan 24(2):151-158

McFadden D (1974) The measurement of urban travel demand. J Public Econ 3(4):303-328

Ministry of Foreign Affairs of Japan (2017) The 2030 agenda for sustainable development and Japan's implementation https://www.mofa.go.jp/policy/oda/sdgs/pdf/japans_efforts.pdf Accessed 6 June

Moore G (2004) The fair trade movement: parameters, issues and future research. J Bus Ethics 53(1/2):73-86. https://doi.org/1 0.1023/B:BUSI.0000039400.57827.c3

Netemeyer RG, Krishnan B, Pullig C, Wang G, Yagci M, Dean D, Ricks J, Wirth F (2018) Developing and validating measures of facets of customer-based brand equity. J Bus Res 57:209-224

Newholm T, Shaw D (2007) Studying the ethical consumer: a review of research. J Consum Behav 6:253-270

Nyilasy G, Gangadharbatla H, Paladino A (2014) Perceived greenwashing: the interactive effects of green advertising and corporate environmental performance on consumer reactions. J Bus Ethics 125(4):693-707

Pardon P, Reubens B, Mertens J, Verheyen K, De Frenne P, De Smet G, Van Waes C, Reheul D (2018) Effects of temperate agroforestry on yield and quality of different arable intercrops. Agric Syst 166(Auqust):135-151. https://doi.org/10.1016/.jagsy.2018.08.008

Park CS, Srinivasan V (1994) A survey-based method for measuring and understanding brand equity and its extendibility. J Mark Res 31(2):271-288

Poelman A, Mojet J, Lyon D, Sefa-Dedeh S (2008) The influence of information about organic production and fair trade on preferences for and perception of pineapple. Food Qual Prefer 19(1):114-121

R Core Team (2018) R: a language and environment for statistical computing. R Foundation for Statistical Computing, Vienna https://www.R-project.org. Accessed 6 Mar 2019

Raynolds LT (2009) Mainstreaming fair trade coffee: from partnership to traceability. World Dev 37(6):1083-1093. https://doi. org/10.1016/j.worlddev.2008.10.001

Rousseau S, Vranken L (2011) The impact of information on the willingness-to-pay for labeled organic food products. SSRN doi: https://doi.org/10.2139/ssrn.1859285

Schrage EJ, Ewing AP (2005) The cocoa industry and child labor. J Corp Citizen 17:99-112

Sigel BJ, Sherry TW, Young BE (2006) Avian community response to lowland tropical rainforest isolation: 40 years of change at La Selva Biological Station, Costa Rica. Conserv Biol 20:111-121

Singh JJ, Iglesias O, Batista-Foguet JM (2012) Does having an ethical brand matter? The influence of consumer perceived ethicality on trust, affect and loyalty. J Bus Ethics 111(4):541-549

Tallontire A, Rentsendorj E, Blowfield M (2001) Ethical consumers and ethical trade: a review of current literature. Policy Ser 12:34

The Soil Association (2017) Come clean about beauty https:/umw.soilassociation.org/media/11393/c4c-report-3.pdf. Accessed 6 Mar 2019

Tscharntke T, Clough Y, Bhagwat SA, Buchori D, Faust H, Hertel D et al (2011) Multifunctional shade-tree management in tropical agroforestry landscapes - a review. J Appl Ecol 48(3):619-629

Tully SM, Winer RS (2014) The role of the beneficiary in willingness to pay for socially responsible products: a meta-analysis. J Retail 90:255-274

United Nations (2015) Goal 12: Ensure sustainable consumption and production patterns. https://www.un.org/ sustainabledevelopment/sustainable-consumption-production/. Accessed 4 Jul 2019

Van Bael SA, Bichier P, Ochoa I, Greenberg R (2007) Bird diversity in cacao farms and forest fragments of Western Panama. Biodivers Conserv 16(8):2245-2256

Wheeler B (2006) The AlgDesign package version 1.0-7 http://ftp.uni-bayreuth.de/math/statlib/R/CRAN/doc/packages/ AlgDesign.pdf. Accessed 5 Mar 2019

World Bank (2016) Poverty and shared prosperity 2016: taking on inequality https://openknowledge.worldbank.org/bitstream/ handle/10986/25078/9781464809583.pdf. Accessed 5 Mar 2019

World Fair Trade Organization (2017) 10 principles of fair trade https:/wfto.com/fair-trade/10-principles-fair-trade. Accessed 5 Mar 2019

\section{Publisher's Note}

Springer Nature remains neutral with regard to jurisdictional claims in published maps and institutional affiliations. 